\title{
Ultaco Game Development as a Media to Introduce Covid-19 Health Protocol in Early Childhood
}

\author{
M. Fadlillah ${ }^{*}$, Rendy Setyowahyudi ${ }^{2}$
}

DOI: 10.35445/alishlah.v13i1. 532

Info Artikel

Keywords:

Ultaco Games

Health Protocol

Covid-19

Early Childhood

Kata kunci:

Permainan Ultaco

Protokol Kesehatan

Covid-19

Anak usia dini

\begin{abstract}
The most effective way to prevent the spread of Covid-19 is to comply with health protocols. However, this habit is still tricky for some Indonesians, including in early childhood. This study aimed to develop and test the Ultaco game's quality as a medium in introducing the Covid-19 health protocol to early childhood. The research and development (R\&D) method was used in this study. In developing the Ultaco game, three steps carried out, including planning, design, and development. Product quality testing was carried out using three techniques: alpha test, beta test, and final evaluation. This study showed that the Ultaco game is a kind of snakes and ladders game that contains the Covid19 health protocol, including wearing a mask, maintaining distance, staying at home, washing hands, covering sneezes, exercising diligently, and eating nutritiously. The trial results showed that the Ultaco game is of good quality and is suitable for use as a medium for introducing the Covid-19 health protocol to early childhood. This is based on the average score of the alpha test score of 4.48 , the beta test score of 3.41 , and the final evaluation score of 3.64 . This study implies that children can become accustomed to complying with the Covid-19 health protocol with attractive, fun, and fun game media.
\end{abstract}

\begin{abstract}
Abstrak
Cara paling efektif untuk mencegah penyebaran Covid-19 adalah dengan mematuhi protokol kesehatan. Namun kebiasaan tersebut masih sulit dilakukan oleh sebagian masyarakat Indonesia, termasuk anak usia dini. Tujuan penelitian ini adalah untuk mengembangkan dan menguji kualitas permainan Ultaco sebagai media dalam mengenalkan protokol kesehatan Covid-19 pada anak usia dini. Metode research and development (R\&D) digunakan dalam penelitian ini. Dalam pengembangan permainan Ultaco dilakukan dengan tiga langkah, yaitu planning, desain, dan pengembangan. Untuk pengujian kualitas produk dilakukan dengan tiga teknik yaitu alpha test, beta test, dan evaluasi akhir. Hasil penelitian ini adalah permainan Ultaco adalah sejenis permainan ular tangga yang di dalamnya memuat protokol kesehatan covid-19, meliputi: memakai masker, jaga jarak, di rumah saja, mencuci tangan, menutup bersin, rajin berolahraga, dan makan bergizi. Hasil ujicoba menunjukkan bahwa permainan Ultaco memiliki kualitas baik dan layak digunakan sebagai media untuk mengenalkan protokol kesehatan Covid19 pada anak usia dini. Hal ini didasarkan pada hasil rata-rata skor penilaian alpha test yaitu 4,48, skor penilaian beta tes 3,41 , dan sekor penilaian evaluasi akhir 3,64. Implikasi dari penelitian ini adalah anak-anak dapat terbiasa
\end{abstract}

\footnotetext{
1*Pendidikan Guru Pendidikan Anak Usia Dini, Universitas Muhammadiyah Ponorogo, Indonesia. Email: fadly ok@yahoo.co.id

${ }^{2}$ Pendidikan Guru Pendidikan Anak Usia Dini, Universitas Muhammadiyah Ponorogo, Indonesia.

Email: rendy.Setyowahyudi@yahoo.co.id
} 
mematuhi protokol kesehatan covid-19 dengan media permainan yang menarik, asyik, dan menyenangkan.

\section{INTRODUCTION}

Currently, the world is being hit by a catastrophic outbreak of the Covid-19 pandemic caused by the coronavirus (Mahanani, 2020). Covid-19 infection cases have occurred in various countries, such as China, Thailand, Japan, South Korea, Singapore, Vietnam, the United States, and 24 other worldwide (Tian et al., 2020). Covid-19 is a global pandemic that has hit almost all countries (Di Gennaro et al., 2020; Marques de Miranda et al., 2020). In Indonesia, the first case of covid-19 occurred in March 2020, as announced by the President. The cases continue to increase every day until now (Ihsanuddin, 2020). This virus first appeared in December 2019 in Wuhan, South China and was declared a health emergency in various countries (Ahmad, 2020; Fu et al., 2020; Shereen et al., 2020; Singhal, 2020). It is known that this virus can infect the human respiratory system through droplets from people who speak, cough or sneeze, then this virus enters and infects other people through the mouth, nose and eyes (Novianty, 2020). The symptoms include fever, cough, sore throat, shortness of breath, fatigue, and malaise (Ahmad, 2020). The World Health Organization (WHO) has named Covid-19 a disease caused by Coronavirus 2 (SARS-CoV-2), where the virus is very contagious and can cause infections in the acute respiratory tract (Barry, Dana M.; Kanematsu, 2020; Hu et al., 2020; Shereen et al., 2020).

The Ministry of Health and the Task Force for the Acceleration of Handling Covid-19 had issued a guideline in the form of a Covid-19 health protocol that must be adhered to as prevention to not suffer from Covid-19. The contents of the health protocol include maintaining hand hygiene, avoiding touching the face, applying the ethics of coughing and sneezing, wearing a mask, maintaining distance, isolating independently, and maintaining health. In addition, World Health Organization (WHO) has also issued new guidelines for health protocol for Covid-19 on Thursday, July 9, 2020. In addition to a previous protocol such as washing hands, wearing masks, keeping your distance, ensuring good ventilation, and wearing a mask in a closed room (Dinisari, 2020). By obeying the application of health protocol and keeping the surrounding environment clean and wellmaintained, the transmission of Covid-19 can be prevented as early as possible (Ichsan et al., 2020). The Covid-19 pandemic has created various unexpected and unprecedented challenges (Laufs \& Waseem, 2020). This pandemic also affects all sectors of human life, including the education sector (Barry, Dana M.; Kanematsu, 2020; Crawford, 2020; Mehmet \& Assist, 2020; Toquero, 2020). Many schools and universities have had to close schools for teaching and learning activities and replaced with distance learning because of the very fast transmission of the Covid-19 disease (Mehmet \& Assist, 2020). Besides, it has also caused an economic crisis (DeWit et al., 2020).

Public awareness is needed in adhering to health protocols. Unfortunately, many people do not have awareness, such as wearing masks and keeping their distance. According to Syamsuar (2020), the transmission of Covid-19 has occurred so far because of the lack of public awareness in complying with health protocols. In line with that, Prabawati (2021) explained that the public's ignorance of $5 \mathrm{M}$ (Wearing Masks, Keeping Distance, Washing Hands, Staying Away from the Crowd and Reducing Mobility) makes the potential for Covid 19 transmission in the community to remain high. Apart from adults, awareness and habits of complying with health protocols also need to be carried out by early childhood. This is because covid-19 can also affect children. According to the Indonesian Pediatrician Association chairman, more than 40 children died with a positive status of Covid-19 and more than 200 children deaths. The latter were patients under surveillance by the end of June 2020 (Wijaya, 2020). Of course, this situation is very worrying because the state must lose its golden age children who will become the nation's successors. This virus has been confirmed to attack various groups, but several groups are most at risk, namely the elderly and early childhood (Marques de Miranda et al., 2020; Wijaya, 2020). The number of children with coronavirus disease-2019 (Covid19) has also increased significantly (She et al., 2020). For this reason, the habit of complying with the Covid-19 health protocol needs to be introduced and instilled in early childhood. 
Particularly in early childhood, explaining the various covid-19 health protocol cannot only be done in words of mouth. An exciting way is needed so that children can understand and apply the different covid-19 health protocol correctly. Early childhood is the time to play. They learn through playing (Cheung \& McBride, 2017). Therefore, a suitable way to explain the Covid-19 protocol to early childhood is through games. Theoretically, it is explained that games are fun and enjoyable activities that can encourage each individual to explore (John W. Santrock, 2017). In line with that, it is stated that playing is a means for children to facilitate the learning process, where they try out their ideas, ask and question various problems, and get answers to their issues (Wulanyani, 2014). Students will be more excited and interested and actively involved in learning (Nugroho et al., 2013). Thus, it can be understood that through playing, early childhood can learn many things, including getting to know the Covid-19 health protocol.

Introducing the Covid-19 health protocol to early childhood is an exciting and fun way. It is necessary to develop a form of games that children like. One type of game that can be developed is the snakes and ladders game. The snakes and ladders game was chosen to introduce the Covid-19 health protocol. Based on several previous studies, it was known that the snakes and ladders game could increase children's learning enthusiasm and make it easier to memorize and practice teamwork (Golchai et al., 2012). Many studies have shown the advantages of playing with snakes and ladders for early childhood learning media. Snakes and ladders game is a great learning activity for early childhood (Gough, 2001). These games can also improve English vocabulary for early childhood (Wulansari \& Azizah, 2018). The use of snakes and ladders to increase children's health knowledge is better than using the health lecture method to improve the same aspect (Wulansari \& Azizah, 2018).

The game of snakes and ladders was developed by Hindu religious leaders, Gyandev, to teach children about appreciation. The snake symbolises bad or evil, while the ladder represents good and truth (Wulanyani, 2014). In English, the game is called Snakes and ladders (Golchai et al., 2012). The snakes and ladders game is one type of game that is quite popular in Indonesia (Noviana, 2010). This game is very familiar in the world of children. Besides exciting and fun, it's also effortless to play. Therefore, this snakes and ladders game is appropriate if used as a learning medium for early childhood. It is widely believed that early childhood is a world of play. The principle of early childhood learning is through playing(Alotibi, 2020; Milteer et al., 2012). Children learn through play, and play is their child's learning (Britton, 1992; Ciolan, 2013; Marks, 2016; Zeece \& Graul, 1990).

The game of snakes and ladders, when used as a learning medium, has several advantages, including creating a pleasant learning atmosphere, stimulating students to carry out individual or group learning activities, having the cognitive structures obtained by students as a result of the learning process stable and are arranged in a relevant manner so that it will be kept in memory. The knowledge in the memory (mind) can be retrieved at any time (Wulanyani, 2014). Several studies have shown that the game of snakes and ladders helps help children to understand better nouns and speaking skills in English (Musa et al., 2016; Sapungan, 2014; Sofyan et al., 2019). Snakes and ladders board games have the potential to promote students' desire to talk within peers group. Despite some difficulties, students seem to enjoy learning (Arfani \& Sulistia, 2019). In addition, this game media can be useful for increasing students activity, enthusiasm for learning, and having the courage to express opinions that will have an impact on increasing students learning outcomes, and make it easier for teachers to deliver learning material (DeWit et al., 2020). The benefits of playing snakes and ladders are also related to students development, including: training motor skills, practising concentration, increasing socialization skills (including competition), training language skills, gaining insight, developing skills for problem-solving, developing leadership skills, developing knowledge of norms and value, increasing self-confidence (Rifa, 2012; Supriatna, 2011). In addition, the game of snakes and ladders can also be useful for developing intellectual intelligence, developing 
emotional intelligence, developing creativity, making children creative, becoming a medium for therapy for children, and developing children's multiple intelligence (Nurhayati, 2012).

Ultaco is a type of snakes and ladders game. Ultaco itself has the meaning of the Covid-19 snakes and ladders. This game adapts the game of snakes and ladders, but it describes efforts to prevent Covid-19 by introducing health protocol in early childhood. The history of the game of snakes and ladders states that the game of snakes and ladders was initially named "Paramapada Sopanam" (Ladder to Salvation) (Wulansari \& Azizah, 2018). The snakes and ladders game is a board game for children played by 2 or more people. The game board is divided into small squares and on some of the squares, several "ladders" or "snakes" are drawn, connecting the boxes. From the various descriptions, it can be understood that the game of snakes and ladders can be used as a learning medium for children. For this reason, it is very appropriate when this game of snakes and ladders is used as a means of introducing the Covid-19 health protocol to early childhood, especially during a pandemic like now. Hopefully, through this game of snakes and ladders, will help disseminate and socialize health protocol to reduce and prevent the spread of Covid-19 in the community.

Based on some of these studies, this study aimed to develop a game of snakes and ladders to introduce the Covid-19 health protocol. This research is fundamental to do to help early childhood know the Covid-19 health protocol. The game to be developed is named Ultaco, namely the Covid-19 Snakes and Ladders. With the Ultaco game created, it is hoped to help socialize the Covid-19 health protocol to early childhood in a more exciting and fun way. By getting to know the Covid-19 health protocol, children will apply it in their daily lives. This condition is indirectly able to help prevent the occurrence of Covid-19 transmission in early childhood.

\section{METHODS}

To develop and produce game products of Ultaco game (the Covid-19 snakes and ladders), this research used the research and development (R\&D) method. This method was chosen because it is very appropriate and under the research objectives, namely to produce a game product to introduce the Covid-19 health protocol to early childhood. R\&D is the process of developing a specific existing product to make it more perfect (Borg, 2007). The method was intended to produce products tested for feasibility and effectiveness (Sugiyono, 2011). The resulting products can be software or hardware, such as books, modules, learning programs, and learning aids (Borg, 2007). In this research, the product to be developed and produced is a learning aid called Ultaco. Ultaco game is the short name for the Covid-19 Snakes and Ladders. The Ultaco game media was designed as a medium for introducing the Covid-19 health protocol to early childhood. The development model used refers to the opinion of Borg and Gall (2007), namely developing and testing the feasibility of the product.

\section{Research Settings}

This research was conducted in Ponorogo Regency, East Java Province, Indonesia. The choice of Ponorogo Regency as a research site was due to the large number of parents and early childhood education teachers who still have difficulty creating and developing learning media to introduce the Covid-19 health protocol to early childhood.

\section{Product Trials and Research Participants}

Product trials are carried out in three steps, namely the expert validation, small-scale field trials, and large-scale field trials:

\section{Expert validation}

Expert validation is a product trial conducted by involving two validators, namely a material expert and a media expert. In this study, the validator will provide an assessment of the products produced. The assessment was carried out by filling in the instruments prepared by the researcher. The assessment results and various inputs from the validator were used as material for revising the product to make it more perfect. After that, the subsequent trial was carried out. 


\section{Small-scale field trials}

Small-scale field trials is a trial that was done after the expert validation. This trial has involved users, but the number is still limited. Therefore, beta test trials are often referred to as limited trials. In this beta test trial, the subjects for the trial were 10 early childhood. After conducting the trial, each child was asked to assess the Ultaco game products' quality. The assessment results and various inputs during this limited trial were used to revise the product before testing more widely to the user.

This study consisted of 10 early childhood children from 2 kindergartens (TK) in Ponorogo Regency. These ten children were selected based on age, namely 4-6 years.

3. Large-scale field trials

The large-scale field trials were the last stage to determine the quality of the product produced. The final evaluation was carried out in this study by testing on a large or broader scale involving 40 early childhood students from 10 kindergartens (TK). This trial aimed to determine children's interest in playing Ultaco. In addition, an Ultaco game quality assessment was also conducted to introduce the Covid-19 health protocol to early childhood. The children's questionnaire was filled in, assisted by teachers and people, based on their observations when they played Ultaco.

The subjects in this research consisted of 40 early childhood children from 10 kindergartens (TK) in Ponorogo Regency selected based on the ages of 4-6 years. This final evaluation involved children in several early childhood education institutions, namely, each institution becoming the final evaluation site according to their needs.

\section{Data Collection}

Collecting data in this study used a questionnaire containing several written statements intended for the specified respondents. This questionnaire consists of a questionnaire for material experts and media experts, a questionnaire for small-scale field trials, and a questionnaire for largescale field trials. This questionnaire will be used as an assessment tool regarding the quality of Ultaco games as a medium for introducing the Covid-19 health protocol to early childhood. The results of the assessment were then described in the form of qualitative data.

\section{FINDINGS AND DISCUSSION}

Prevention of the spread of Covid-19 must be carried out in various ways and strategies. The first step that can be taken is to recognize and know the Covid-19 health protocol. The introduction of this health protocol can teach clean and healthy living habits to prevent and avoid Covid-19. The Ultaco is a type of snakes and ladders game designed and created to introduce the Covid-19 health protocol. The Ultaco game development aimed to introduce the Covid-19 health protocol to early childhood. There were two main questions in this research, namely: 1) how is the development and form of Ultaco games, and 2) what is the appropriateness of the Ultaco game to introduce the Covid19 health protocol to early childhood. Referring to these two questions, the results of this study can be explained as follows:

\section{Development and form of Ultaco games}

Ultaco game development started with making Ultaco image designs and displays. Making this game design was done by utilizing the CorelDraw application. It took one month to make Ultaco designs.

The Ultaco games were designed and developed to introduce early childhood to the Covid-19 health protocol. Through this developed game, hopefully, it can be used as a medium for children to recognize and comply with the health protocol established by World Health Organization (WHO) and the Indonesian government's Covid-19 Handling Task Force. In addition, to introduce daily activities or activities that violate the Covid-19 health protocol. Thus, children become accustomed to implementing the Covid-19 health protocol properly and correctly so that they can avoid the spread of Covid-19. 
The Ultaco form of playing has a size of $33 \times 26 \mathrm{~cm}$. It has 100 squares measuring $2 \times 2 \mathrm{~cm}$. Each square has a variety of colours, and there are numbers from one to one hundred. Eight boxes containing images comply with the Covid-19 health protocol, and eight boxes containing images that violate the Covid-19 health protocol. In addition, there are pictures of ladders, snakes, and the coronavirus in this game. The images in the Ultaco game were designed very attractively according to the level of early childhood development. The material for this game is 260 grams of ivory paper so it is more durable and safe for use by children. Ultaco games also come with dice and pawns to play with. Ultaco game display can be seen in Figure 1.

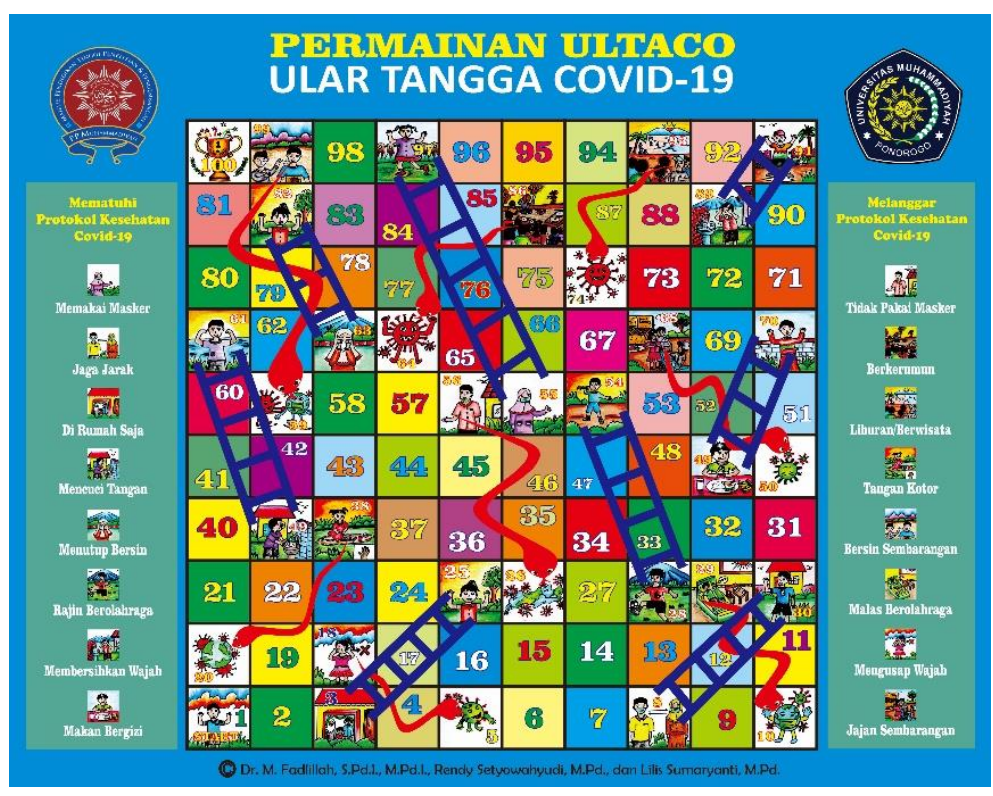

Figure 1. Display of Ultaco game

The Covid-19 health protocol in the Ultaco game is grouped into two, namely, the attitude of complying with the Covid-19 health protocol and the perspective of violating the Covid-19 health protocol. Forms of attitudes adhering to the Covid-19 health protocol include: wearing a mask, keeping the distance, staying at home, washing hands, covering sneezes, exercising diligently, and eating nutritiously. Forms of violating the Covid-19 health protocol include: not wearing masks, gathering in a crowd, travelling, having dirty hands, being lazy to exercise, rubbing the face, and snacking carelessly.

At least two children play the Ultaco game, where each child plays alternately. The winner in the Ultaco game is the fastest player who reaches the box with the number 100. Thus, the game can be ended and started again according to the agreement of each child.

The procedure to play Ultaco is, in principle, the same as playing snakes and ladders in general. The steps in playing Ultaco are: a) the children prepare Ultaco game sheets, dice, and pawns; b) the children decide the order in which the participants play; c) the children alternately roll and drop the dice and then count the numbers; $d$ ) if the child scores a 6 in rolling the dice, he/she gets a bonus to roll the dice once; e) if a pawn carried by a child falls, in the box with a ladder containing the Covid19 health protocol, he/she gets a bonus for jumping or climbing stairs; $f$ ) If a pawn carried by a child falls on a snake drawing box containing a prohibition on the Covid-19 health protocol, he/she will be punished with falling / sliding according to the length of the snake and g) the child who can reach box number 100 is the winner.

\section{The feasibility of playing Ultaco in introducing the Covid-19 health protocol.}

After the Ultaco game was successfully created and developed, various trials were carried out to determine its feasibility in introducing the Covid-19 health protocol to early childhood. There were three forms of testing conducted, namely alpha test, beta test, and final evaluation. Alpha test is the activity of validating Ultaco game products before they are used for testing with users. The activity 
was carried out by involving one material expert in the Covid-19 health sector and one learning media expert in early childhood education. The beta test is a limited trial activity involving 10 early childhood. The final evaluation is a broad trial involving 40 early childhood children in Ponorogo Regency. The results of this Ultaco game trial can be explained as follows:

a. Expert validation

The validation test involving material experts and media experts showed that the Ultaco game was very good for introducing the Covid-19 health protocol in early childhood. The assessment score obtained from the material expert was 4.5 out of the 20 statement items that appear in the validation instrument. If the average score is converted, the assessment score is in the very good category, $\mathrm{X}>$ 4.2. The assessment score from media experts was 4.46 out of 13 statement items that appear in the validation instrument. If the conversion of the average score is carried out, the assessment score is in the very good category, where $4.2<\mathrm{X}$. This assessment score can be seen in Table 1 below:

Table 1. Expert validation scores

\begin{tabular}{cccccc}
\hline No. & Validator & $\begin{array}{c}\text { The number } \\
\text { of } \\
\text { statements }\end{array}$ & $\begin{array}{c}\text { The number } \\
\text { of } \\
\text { assessment } \\
\text { scores }\end{array}$ & $\begin{array}{c}\text { The mean of } \\
\text { assessment } \\
\text { scores }\end{array}$ & $\begin{array}{c}\text { Assessment } \\
\text { Category }\end{array}$ \\
\hline $\mathbf{1}$ & Material Expert & 20 & 90 & 4.5 & Very good \\
\hline $\mathbf{2}$ & Media Expert & 13 & 58 & 4.46 & Very good \\
\hline
\end{tabular}

The material expert gives the inputs suggestion, and the media expert on the development of the Ultaco game includes displaying several pictures showing the activities of complying with and violating the Covid-19 health protocol that must be clarified so that children can understand the meaning. In addition, it is necessary to explain the forms of Covid-19 health protocol activities in the Ultaco game display so that children can read and recognize them one by one. From this alpha test activity, it can be understood that the Ultaco game can be used as a medium to introduce the Covid19 health protocol to early childhood.

b. Small-scale field trials

Small-scale field trials were carried out after the Ultaco game product was declared good and passed the assessment of the material expert validator and media expert. A limited trial was carried out in this activity involving 10 early childhood children in Ponorogo Regency to play Ultaco. The trial was carried out in the home of each child and still paid attention to health protocol. Based on the results of the limited trial, the overall average assessment score was 3.41. The results of the Ultaco small-scale field trials game can be seen in Figure 2 below:

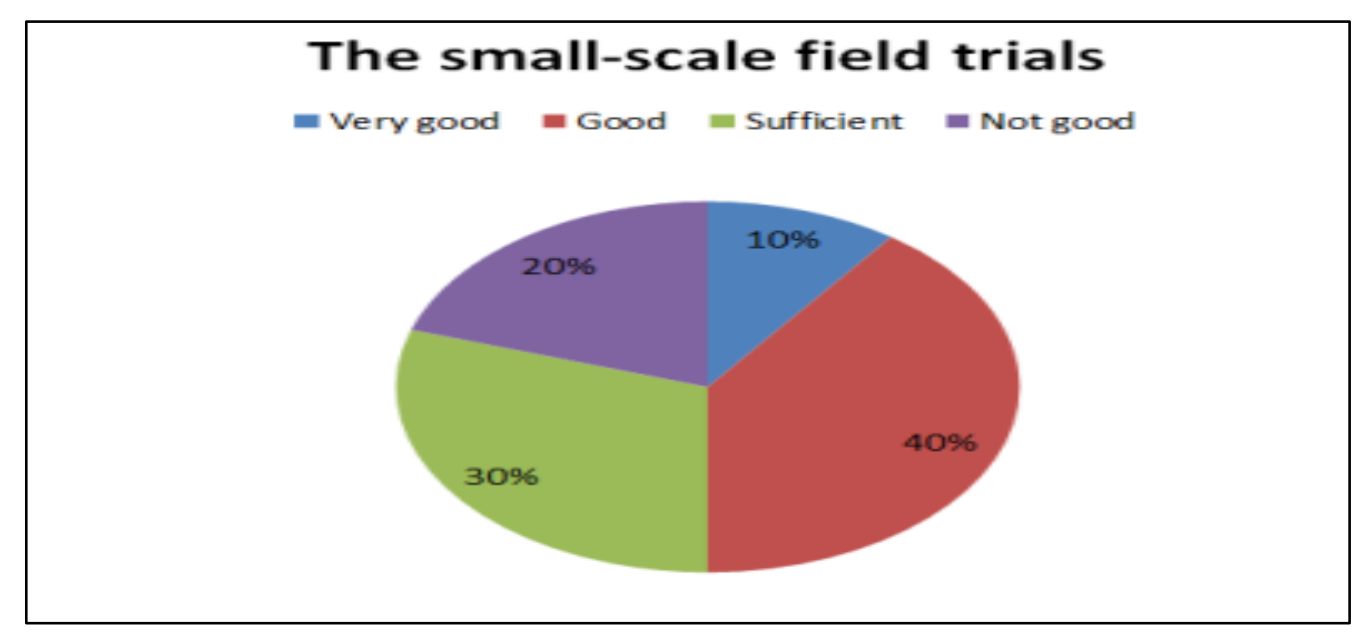

Figure 2. Results of small-scale field trials 
The small-scale field trials showed that 2 children rated the Ultaco game as not good for use, 3 children rated it as sufficient, 4 children rated it good, and 1 child rated it very good. The average score for assessing the beta test results in Figure 2 shows that the Ultaco game is in a good category to be used as a medium for introducing health protocol in early childhood. In the conversion of the mean score, it is stated that if $3.4<\mathrm{X}<4.2$, then the assessment is in a good category.

c. Large-scale field trials

After the expert validation and small-scale field trials stages were passed, the Ultaco game was tested extensively. This trial was intended as a large-scale field trials before Ultaco games were massively produced and used by early childhood. The large-scale field trials were carried out by involving 40 early childhood children in Ponorogo Regency. Based on the results of the broad tests, the overall average score was 3.64. The results of the large-scale field trials of this Ultaco game can be seen in Figure 3 below:

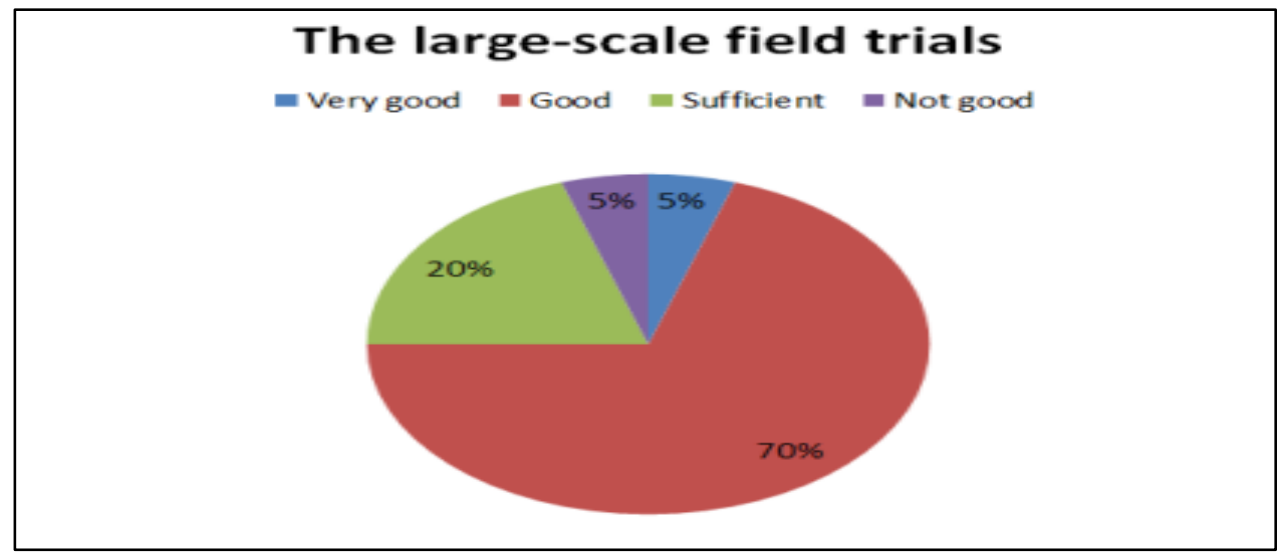

Figure 3. Results of the large-scale field trials

The large-scale field trials data showed that 2 children rated the Ultaco game as not good for use, 8 children rated it as sufficient, 28 children rated it good, and 2 children rated it very well. The average score of the large-scale field trials results in Table 3 shows that the Ultaco game is in a good category to be used as a medium for introducing health protocol in early childhood. In the conversion of the mean score, it is stated that if $3.4<\mathrm{X}<4.2$ and therefore the assessment is in the good category.

The score of the expert validation, small-scale field trials, and large-scale field trials shows that the Ultaco game is suitable for use as a medium for introducing the Covid-19 health protocol to early childhood. The average score of the alpha test is 4.48 , which means it is very good. The average beta test score is 3.41, which means good, and the average final evaluation score is 3.64 , which means good. Thus, it can be concluded that the Ultaco game has a good rating to be suitable for use in early childhood. Through this Ultaco game, children can get to know the Covid-19 health protocol in an exciting and fun way.

Playing tools for early childhood are essential (Milteer et al., 2012). Most of their life is spent playing. Through play, children can learn many things (Cheung \& McBride, 2017), (Ciolan, 2013; Marks, 2016; Zeece \& Graul, 1990). Game tools can be used as learning media. Games make children more excited, interested, and actively involved in learning (Nugroho et al., 2013). Games can encourage children to explore (John W. Santrock, 2017). Many developmental game tools effectively increase children's knowledge, including the game of snakes and ladders (Hadisuyitno, Aswin, Tapriadi, 2017; Nurmaningtyas et al., 2016; Rekysika \& Haryanto, 2019). The game of snakes and ladders can increase children's enthusiasm for learning and make it easier for children to memorize material (Golchai et al., 2012). One of the great learning activities for early childhood is through the snakes and ladders game (Gough, 2001). 
The Ultaco game has proven worthy of being used as a learning medium to introduce the covid19 health protocol in early childhood. The results of previous research indicated that the game of snakes and ladders increased health knowledge in children (Wulanyani, 2014). Other researchers stated that the game of snakes and ladders could be used as a medium to introduce moral education and familiarize children to follow the rules (Ibam et al., 2018; Muh Ibnu Sina, 2017; Syawaluddin et al., 2020). In addition, the Ultaco game is expected to help teachers or schools overcome the mental health of children caused by Covid-19. The community's role is considered important by the community as mitigation not only for Covid-19 but also for children's mental health (Marques de Miranda et al., 2020). Therefore, teachers or schools can take advantage of the Ultaco game as an interesting and fun learning medium to entertain and relieve feelings of stressed children due to the coronavirus. In addition, children can also learn and get to know the Covid-19 health protocol.

The Covid-19 health protocol can be introduced in early childhood through the Ultaco game. The habits of wearing masks, washing hands and maintaining a distance are very important for children to understand to avoid the spread of the coronavirus. For early childhood, the introduction of the Covid-19 health protocol must be packaged in the form of a game. Thus, the Ultaco game can be used as an alternative media in introducing the Covid-19 health protocol in early childhood. Hopefully, is game can help prevent the spread of the coronavirus in early childhood, especially in Indonesia.

Research and development of the Ultaco game are still limited to testing product feasibility, not testing its effectiveness. In the future, it is necessary to test the effectiveness of the Ultaco game as a guide to introduce the Covid-19 health protocol to early childhood. In addition, this game is only suitable for children aged 5 years and over, so children under age cannot use it optimally.

\section{CONCLUSION}

The Covid-19 disaster occurred because people didn't comply with health protocol. Early childhood is no exception. The Ultaco game were designed and developed to introduce the Covid-19 health protocol to early childhood. This game is very suitable to be used as a Covid-19 learning medium. The research data showed that the average score of the alpha test assessment was 4.48, the beta test score was 3.41, and the final evaluation score was 3.64. Thus, it can be understood that the Ultaco game obtained good ratings and was worthy of use. Therefore, hopefully, children will recognize and get used to complying with the Covid-19 health protocol through this game. Furthermore, the development of this game can help prevent the spread of the coronavirus, especially in early childhood in Indonesia.

\section{ACKNOWLEDGEMENT}

We would like to express our gratitude to the Council of Higher Education, Research and Development of the Head of Central Muhammadiyah, who have funded this entire research. Thank you also to Universitas Muhammadiyah Ponorogo, who have fully supported research activities from beginning to ending.

\section{REFERENCES}

Ahmad, S. (2020). A Review of COVID-19 (Coronavirus Disease-2019) Diagnosis, Treatments and Prevention. Eurasian Journal of Medicine and Oncology. https://doi.org/10.14744/ejmo.2020.90853

Alotibi, S. F. (2020). Play based-learning in early childhood education: Teachers' perception in head start and Montessori programs. Dissertation Abstracts International Section A: Humanities and Social Sciences.

Arfani, S., \& Sulistia, A. (2019). Teaching speaking using a snake and ladder board game: A Teacher story. Research and Innovation in Language Learning. https://doi.org/10.33603/rill.v2i1.1642

Barry, Dana M.; Kanematsu, H. (2020). Teaching during the COVID-19 Pandemic. Erik. 
https://eric.ed.gov/?q=TEACHING+DURING+THE+COVID-19+PANDEMIC\&id=ED606017

Borg, \& G. (2007). An Introduction Education Research (8th ed). Pearson Education, Inc.

Britton, L. (1992). Montessori Play \& Learn: A Parents' Guide to Purposeful Play from Two to Six. Crown Publishers, Inc.

Cheung, S. K., \& McBride, C. (2017). Effectiveness of Parent-Child Number Board Game Playing in Promoting Chinese Kindergarteners' Numeracy Skills and Mathematics Interest. Early Education and Development. https://doi.org/10.1080/10409289.2016.1258932

Ciolan, L. E. (2013). Play to Learn, Learn to Play. Creating Better Opportunities for Learning in Early Childhood. Procedia - Social and Behavioral Sciences. https://doi.org/10.1016/j.sbspro.2013.04.096

Crawford, J. (2020). COVID-19: 20 Countries' higher education intra-period digital pedagogy responses. Journal of Applied Teaching and Learning (JALT), 3(1), 1-20. https://doi.org/https://doi.org/10.37074/jalt.2020.3.1.7

DeWit, A., Shaw, R., \& Djalante, R. (2020). An integrated approach to sustainable development, National Resilience, and COVID-19 responses: The case of Japan. In International Journal of Disaster Risk Reduction. https://doi.org/10.1016/j.ijdrr.2020.101808

Di Gennaro, F., Pizzol, D., Marotta, C., Antunes, M., Racalbuto, V., Veronese, N., \& Smith, L. (2020). Coronavirus diseases (COVID-19) current status and future perspectives: A narrative review. In International Journal of Environmental Research and Public Health. https://doi.org/10.3390/ijerph17082690

Dinisari, M. C. (2020). WHO rilis pedoman baru protokol kesehatan penyebaran virus corona di udara. https://lifestyle.bisnis.com/ read/20200710/106/1264152/who-rilis-pedoman-baruprotokol-kesehatan-penyebaran-virus-corona-di-udara

Fu, L., Wang, B., Yuan, T., Chen, X., Ao, Y., Fitzpatrick, T., Li, P., Zhou, Y., Lin, Y. fan, Duan, Q., Luo, G., Fan, S., Lu, Y., Feng, A., Zhan, Y., Liang, B., Cai, W., Zhang, L., Du, X., ... Zou, H. (2020). Clinical characteristics of coronavirus disease 2019 (COVID-19) in China: A systematic review and meta-analysis. Journal of Infection. https://doi.org/10.1016/j.jinf.2020.03.041

Golchai, B., Nazari, N., Hassani, F., Nasiri, E., nejad, R. G., \& Jafari, Z. (2012). Snakes and Ladders: A New Method for Increasing of Medical Students Excitement. Procedia - Social and Behavioral Sciences. https://doi.org/10.1016/j.sbspro.2012.06.954

Gough, J. (2001). Dice and board games. Australian Primary Mathematics Classroom, 6(1), 14-17.

Hadisuyitno, Aswin, Tapriadi, and U. (2017). Penggunaan media permainan ular tangga pada pembelajaran PIPS untuk meningkatkan hasil belajar siswa pada materi pembagian wilayah waktu di Indonesia. Jurnal Pena Ilmiah. https://doi.org/10.17509/jpi.v2i1.12425

Hu, B., Guo, H., Zhou, P., \& Shi, Z. L. (2020). Characteristics of SARS-CoV-2 and COVID-19. In Nature Reviews Microbiology. https://doi.org/10.1038/s41579-020-00459-7

Ibam, E., Adekunle, T., \& Agbonifo, O. (2018). A Moral Education Learning System based on the Snakes and Ladders Game. EAI Endorsed Transactions on E-Learning. https://doi.org/10.4108/eai.25-9-2018.155641

Ichsan, I. Z., Rahmayanti, H., Purwanto, A., Sigit, D. V., Irwandani, I., Ali, A., Susilo, S., Kurniawan, E., \& Rahman, M. M. (2020). COVID-19 Outbreak on Environment: Profile of Islamic University Students in HOTS-AEP-COVID-19 and PEB-COVID-19. Tadris: Jurnal Keguruan Dan Ilmu Tarbiyah. https://doi.org/10.24042/tadris.v5i1.6283

Ihsanuddin. (2020). Fakta Lengkap Kasus Pertama Virus Corona di Indonesia. Kompas.com

John W. Santrock. (2017). LIFE-SPAN Development (13th ed.). In McGraw-Hill.

Laufs, J., \& Waseem, Z. (2020). Policing in pandemics: A systematic review and best practices for police response to COVID-19. International Journal of Disaster Risk Reduction. https://doi.org/10.1016/j.ijdrr.2020.101812

Mahanani, R. (2020). Perbedaan Virus Corona dan Covid-19 Beserta Kepanjangannya, Wajib Tahu. Kids.Grid.Id. https://kids.grid.id/read/472113686/perbedaan-virus-corona-dan-covid19-beserta-kepanjangannya-wajib-tahu?page=all

Marks, L. (2016). Playing to Learn: an overview of the Montessori Approach with pre-school children with Autism Spectrum Condition. Support for Learning. https://doi.org/10.1111/14679604.12140

Marques de Miranda, D., da Silva Athanasio, B., Sena Oliveira, A. C., \& Simoes-e-Silva, A. C. (2020). How is COVID-19 pandemic impacting mental health of children and adolescents? In International Journal of Disaster Risk Reduction. https://doi.org/10.1016/j.ijdrr.2020.101845 
Mehmet, F., \& Assist, C. (2020). Slowmation Experiences Of Pre-Service Teachers Via Distance Education During The Covid-19 Pandemic Disease. In International Online Journal of Primary Education.

Milteer, R. M., Ginsburg, K. R., Mulligan, D. A., Ameenuddin, N., Brown, A., Christakis, D. A., Cross, C., Falik, H. L., Hill, D. L., Hogan, M. J., Levine, A. E., O’Keeffe, G. S., Swanson, W. S., Siegel, B. S., Dobbins, M. I., Earls, M. F., Garner, A. S., McGuinn, L., Pascoe, J., \& Wood, D. L. (2012). The importance of play in promoting healthy child development and maintaining strong parentchild bond: Focus on children in poverty. Pediatrics. https://doi.org/10.1542/peds.2011-2953

Muh Ibnu Sina, I. I. (2017). Model permainan ular tangga "s.m.s "(saya memang sholih) sebagai pengembangan intervensi kognitif-perilaku pada anak dengan kecenderungan perilaku menentang. Seminar Nasional Bahasa, Sastra, Dan Budaya, 1(1), 440-445. http://eproceedings.umpwr.ac.id/index.php/bahtera/article/view/34

Musa, A., Ariffin, N. A., \& Hasan, A. (2016). Noun-it-Right Snake and Ladder Board Game : Learning about Nouns - An Enhancement Tool in the Teaching of Grammar. Creative Practices in Language Learning and Teaching (CPLT).

Noviana, D. (2010). Penggunaan permainan ular tangga untuk meningkatkan kemampuan kognitif anak dalam memahami konsep bilangan 1-10 di TK ABA 01 Batu oleh Dina Novarina. In Penelitian Tindakan Kelas.

Novianty, D. (2020). Begini Cara Virus Corona COVID-19 Menyerang Tubuh Manusia. Www.Suara.Com. https://www.suara.com/tekno/ 2020/03/12/091500/begini-cara-viruscorona-covid-19-menyerang-tubuh-manusia

Nugroho, A., Raharjo, T., \& Wahyuningsih, D. (2013). Pengembangan media pembelajaran fisika menggunakan permainan ular tangga ditinjau dari motivasi belajar siswa kelas VIII mater gaya. Jurnal Pendidikan Fisika.

Nurhayati, I. (2012). Peran Permainan Tradisional Dalam Pembelajaran Anak Usia Dini. Journal Empowerment.

Nurmaningtyas, R., Hadisuyitno, J., Kaswari, S. R. T., \& Riyadi, B. D. (2016). Penyuluhan Pesan Gizi Seimbang Dengan Media Permainan Ular Tangga Terhadap Pengetahuan Gizi Siswa Sekolah Dasar. Jurnal Ilmiah.

Prabawati. (2021). Perlunya Kesadaran Masyarakat. Diskominfo.Kaltimprov.Go.Id, 1. https://diskominfo.kaltimprov.go.id/berita/perlunya-kesadaran-masyarakat

Rekysika, N. S., \& Haryanto, H. (2019). Media pembelajaran ular tangga bilangan untuk meningkatkan kemampuan kognitif anak usia 5-6 tahun. Cakrawala Dini: Jurnal Pendidikan Anak Usia Dini. https://doi.org/10.17509/cd.v10i1.1600o

Rifa, I. (2012). Koleksi Games Edukatif di Dalam dan Luar Sekolah. Flashbook.

Sapungan, G. M. (2014). Parental involvement in child's education: Importance, barriers and benefits. Asian Journal of Management Sciences \& Education, 3(2), 42-48.

She, J., Liu, L., \& Liu, W. (2020). COVID-19 epidemic: Disease characteristics in children. In Journal of Medical Virology. https://doi.org/10.1002/jmv.25807

Shereen, M. A., Khan, S., Kazmi, A., Bashir, N., \& Siddique, R. (2020). COVID-19 infection: Origin, transmission, and characteristics of human coronaviruses. In Journal of Advanced Research. https://doi.org/10.1016/j.jare.2020.03.005

Singhal, T. (2020). A Review of Coronavirus Disease-2019 (COVID-19). In Indian Journal of Pediatrics. https://doi.org/10.1007/s12098-020-03263-6

Sofyan, R., Sinar, T. S., Tarigan, B., \& Zein, T. T. (2019). Using a snake and ladder game in teaching speaking to young learners. ABDIMAS TALENTA: Jurnal Pengabdian Kepada Masyarakat. https://doi.org/10.32734/abdimastalenta.v3i2.4121

Sugiyono. (2011). Metode Penelitian Kuantitatif, kualitatif dan R \&amp; D. Bandung: Alfabeta. https://doi.org/10.1017/CBO9781107415324.004

Supriatna, E. (2011). Model Bermain Edukatif Dalam Pembelajaran Pendidikan Jasmani Anak Usia Prasekolah. Guru Membangun.

Syamsuar. (2020). Kurangnya Kesadaran Masyarakat Patuhi Protokol Kesehatan Jadi Tantangan Pemprov Riau. Ppid.Riau.Go.Id, 1. https://ppid.riau.go.id/berita/633/Kurangnya-KesadaranMasyarakat-Patuhi-Protokol-Kesehatan-Jadi-Tantangan-Pemprov-Riau

Syawaluddin, A., Afriani Rachman, S., \& Khaerunnisa. (2020). Developing Snake Ladder Game Learning Media to Increase Students' Interest and Learning Outcomes on Social Studies in Elementary School. Simulation and Gaming. https://doi.org/10.1177/1046878120921902 
Tian, S., Hu, N., Lou, J., Chen, K., Kang, X., Xiang, Z., Chen, H., Wang, D., Liu, N., Liu, D., Chen, G., Zhang, Y., Li, D., Li, J., Lian, H., Niu, S., Zhang, L., \& Zhang, J. (2020). Characteristics of COVID-19 infection in Beijing. Journal of Infection. https://doi.org/10.1016/j.jinf.2020.02.018

Toquero, C. M. (2020). Challenges and Opportunities for Higher Education amid the COVID-19 Pandemic: The Philippine Context. Pedagogical Research. https://doi.org/10.29333/pr/7947

Wijaya, C. (2020). Siapa saja yang paling rentan terkena dan sakit parah akibat virus corona? Www.Bbc.Com. https://www.bbc.com/indonesia/indonesia-51411440

Wulansari, M., \& Azizah, N. (2018). The Effectivity of Snakes And Ladders Game Media to Improve English Vocabulary of Children. https://doi.org/10.2991/secret-18.2018.35

Wulanyani, M. (2014). Meningkatkan Pengetahuan Kesehatan melalui Permainan Ular Tangga. Meningkatkan Pengetahuan Kesehatan Melalui Permainan Ular Tangga. https://doi.org/10.22146/jpsi.6976

Zeece, P. D., \& Graul, S. K. (1990). Learning to play: Playing to learn. Day Care \& Early Education. https://doi.org/10.1007/BF01620033 